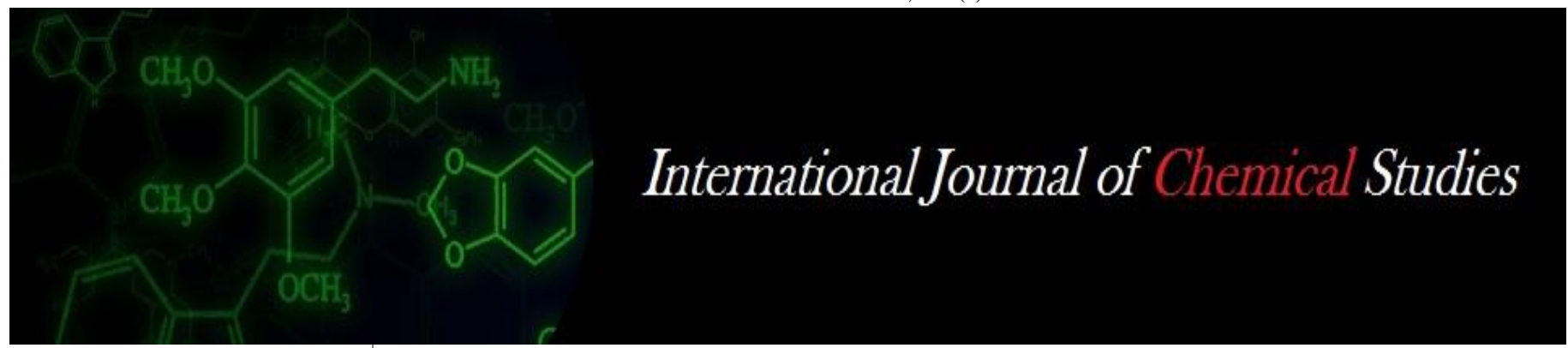

P-ISSN: 2349-8528

E-ISSN: 2321-4902

www.chemijournal.com

IJCS 2020; SP-8(4): 470-471

(C) 2020 IJCS

Received: 06-05-2020

Accepted: 22-06-2020

\section{KD Tankodara}

Ph.D. Scholar, Department of

Agricultural Extension \&

Communication, A.A.U., Anand,

Gujarat, India

\section{GR Gohil}

Extension Educationist,

Directorate of Extension

Education, J.A.U., Junagadh,

Gujarat, India

\section{Khushboo Bhati}

P.G. Scholar, Department of Agricultural Extension, J.A.U.,

Junagadh, Gujarat, India
Corresponding Author:

GR Gohil

Ph.D. Scholar, Department of Agricultural Extension \&

Communication, A.A.U., Anand,

Gujarat, India

\section{Suggestions offered by the chickpea growers to enhance the adoption of recommended chickpea production technology}

\author{
KD Tankodara, GR Gohil and Khushboo Bhati
}

DOI: https://doi.org/10.22271/chemi.2020.v8.i4h.10265

\begin{abstract}
Chickpea is one of the most important legume crops of Gujarat state. However, it was observed wide gap in between existing yield and potential yield in to the chickpea production. Looking to the importance of the problem, a study was conducted in Junagadh district of Gujarat State to seek the suggestions from the chickpea growers to enhance the adoption of recommended chickpea production technology. Four talukas; Maliya, Keshod, Mendarda and Junagadh of Junagadh district were purposively selected for the research. Total three villages were randomly selected from each selected taluka and 10 farmers were randomly selected from each village. Thus, total sample size was 120 farmers. In this investigation, major suggestions offered by the chickpea growers to enhance the adoption of recommended chickpea production technology were; supply of production inputs should be at subsidized rate (1.87 mean score), produces should be purchased by government at reasonable price (1.80 mean score), provide technical knowledge about insecticide, fungicide and weedicide ( 1.63 mean score), \& water harvesting projects for increase the availability of irrigation water should be developed (1.43 mean score).
\end{abstract}

Keywords: Chickpea growers, chickpea production technology, adoption, suggestions

\section{Introduction}

In the process of agricultural development, new farming technology can be considered as the prime mover. The benefits of such technology are actually derived only when it is efficiently utilized by the individual farmers in their local situations. But only a small percentage of new technologies have been adopted by the farmers. As a result of that, wide gap between existing yield and potential yield can be seen. Chickpea is an important and unique food legume crop because of its economic as well as health related importance. In the production of chickpea, the yield of chickpea was $1253 \mathrm{~kg} / \mathrm{ha}$ in Gujarat in year 2017-18 (Anon., 2018a) ${ }^{[1]}$ which was much lower than the average of the yields $(1700 \mathrm{~kg} / \mathrm{ha}$ for rain fed chickpea and $2450 \mathrm{~kg} / \mathrm{ha}$ for irrigated chickpea) obtained from various varieties at demonstration plot and research station (Anon., 2018b) ${ }^{[2]}$. This might be due chickpea growers' low level of adoption of improved production technology. As a matter of the fact, chickpea growers have certain limitations or problems which hinder them in adoption of innovations. In order to raise the level of adoption of chickpea growers, it is necessary to seek the suggestions from them to overcome the problems faced by them in adoption of recommended production technology. Looking to the importance and urgency of the problem, a study was carried out to seek the suggestions from the chickpea growers to overcome the constraints faced by them and enhance the adoption of recommended chickpea production technology.

\section{Objectives}

To seek the suggestions from the chickpea growers to overcome the constraints faced by them in the adoption of recommended chickpea production technology with a view to enhance their adoption level

\section{Methodology}

The study was conducted in Junagadh district of Gujarat state in year 2019. Junagadh district is one of the leading chickpea growing districts of South Saurashtra Agro-climatic zone of Gujarat State. Out of 9 talukas of Junagadh district, 4 talukas viz. Maliya, Keshod, Mendarda 
and Junagadh were selected purposively for the study due to favorable area of production for chickpea crop and familiar area for researcher. Three villages were selected randomly from the each selected talukas. Thus, total 12 villages were selected for the study. A random sampling procedure was followed for the selection of the respondents and accordingly ten chickpea growers from each village were selected as respondents. Thus, 120 chickpea growers were selected for the study. The data were collected with the help of well structured, pre-tested schedule through personal contact. The chickpea growers were asked to give their responses regarding the suggestions on 3 point rating scale. On that basis, mean scores were calculated for individual suggestions. Overall ranks were assigned on the basis of mean scores. Similar procedures were also followed by Umretiya (2015) ${ }^{[4]}$, and Lohare (2017) ${ }^{[3]}$ for getting appropriate conclusion.

\section{Results and Discussion}

The results in table 1 indicate the suggestions from the chickpea growers to overcome constraints in adoption of recommended chickpea production technology.

Table 1: Suggestions from the chickpea growers to overcome the constraints faced by them in adoption of recommended chickpea production technology $(n=120)$

\begin{tabular}{|c|c|c|c|}
\hline S. No. & Suggestions & Mean score & Rank \\
\hline 1. & Supply of production inputs should be at subsidized rate & 1.87 & I \\
\hline 2. & Produces should be purchased by government at reasonable price & 1.80 & II \\
\hline 3. & Provide technical knowledge about insecticide, fungicide and weedicide & 1.63 & III \\
\hline 4. & Water harvesting projects for increase the availability of irrigation water should be developed & 1.43 & IV \\
\hline 5. & More number of training programs should be arranged at village level & 1.35 & $\mathrm{~V}$ \\
\hline 6. & Fencing facilities should be provided at subsidized rate & 1.27 & VI \\
\hline 7. & Provide market facilities at village level & 1.18 & VII \\
\hline 8. & Improved varieties' seeds should be made available at village level & 1.13 & VIII \\
\hline 9. & Market information should be made available at right time at village level & 0.98 & IX \\
\hline 10. & Sufficient and timely credit facilities should be made available & 0.92 & $\mathrm{X}$ \\
\hline 11. & Provide proper information about crop insurance & 0.87 & $\mathrm{XI}$ \\
\hline 12. & Extension workers should frequently contact to the farmers for making them aware about new technology & 0.75 & XII \\
\hline 13. & Regular electricity should be supplied & 0.65 & XIII \\
\hline
\end{tabular}

On the basis of table 1, it can be seen that major suggestions offered by the chickpea growers were; supply of production inputs should be at subsidized rate (1.87 mean score) which got rank $1^{\text {st }}$, followed by produces should be purchased by government at reasonable price (1.80 mean score) and provide technical knowledge about insecticide, fungicide and weedicide (1.63 mean score) which got rank $2^{\text {nd }} \& 3^{\text {rd }}$, respectively. Other suggestions offered by the chickpea growers from rank $4^{\text {th }}$ to $13^{\text {th }}$ were; water harvesting projects for increase the availability of irrigation water should be developed (1.43 mean score), more number of training programs should be arranged at village level (1.35 mean score), fencing facilities should be provided at subsidized rate (1.27 mean score), provide market facilities at village level (1.18 mean score), improved varieties' seeds should be made available at village level (1.13 mean score), market information should be made available at right time at village level (0.98 mean score), sufficient and timely credit facilities should be made available (0.92 mean score), provide proper information about crop insurance (0.87 mean score), extension workers should frequently contact to the farmers for making them aware about new technology ( 0.75 mean score) and regular electricity should be supplied ( 0.65 mean score), respectively.

\section{Conclusion}

On the basis of above mentioned finding, it can be concluded that majority of chickpea growers suggested about supply of production inputs should be at subsidized rate, followed by produces should be purchased by government at reasonable price, provide technical knowledge about insecticide, fungicide and weedicide, water harvesting projects for increase the availability of irrigation water should be developed, more number of training programs should be arranged at village level, and fencing facilities should be provided at subsidized rate.

\section{Implication}

1. The study will serve as a guideline for the planners and extension agencies for planning and implementing various polices on chickpea crop as well as similar pulse crops' production in that area.

2. The study will work as review for the various researchers and enlightening the path in doing similar kind of work.

\section{References}

1. Anonymous. Gram: State-wise yield. Agricultural statistics at a glance 2018. Directorate of economics and statistics, 2018a, $162 . \quad$ Available: http://agricoop.gov.in/sites/default/files/agristatglance201 8.pdf.

2. Anonymous. Characteristics of various varieties of chickpea studied by pulse research station, Junagadh Agricultural University - Junagadh, 2018b.Available: http://www.jau.in/index.php/resources/research-stationstop/south-saurashtra/pulses research-station-junagadh.

3. Lohare R. A study on knowledge and adoption of chickpea production technology among the farmers in Tirla block of Dhar district. M.Sc. (Agri.) Thesis (Unpublished). R.V.S.K.V.V., Gwalior, 2017.

4. Umretiya K. A comparative study on adoption of improved chickpea varieties in Indore district of Madhya Pradesh. M.Sc. (Agri.) Thesis (Unpublished). R.V.S.K.V.V., Gwalior, 2015. 